Article

\title{
Racial and Ethnic Group Spatial Assimilation in Inner and Outer Suburban Rings
}

\author{
Grigoris Argeros $D$ \\ Department of Sociology, Anthropology, and Criminology, Eastern Michigan University, \\ Ypsilanti, MI 48197, USA; gargeros@emich.edu; Tel.: +1-743-487-0456
}

Received: 21 September 2018; Accepted: 7 November 2018; Published: 9 November 2018

\begin{abstract}
The present study examines inner and outer suburban ring attainment outcomes among racial and ethnic groups that reside in the nation's metropolitan areas. The main objective is to evaluate the extent to which the relationship between racial and ethnic group's socioeconomic status characteristics and residence between inner and outer suburban rings conforms to the tenets of the spatial assimilation model. Using micro-level data from the five-year 2012-2016 American Community Survey, the author calculates binomial logistic regression models to determine the effects of socioeconomic status (SES) and other relevant predictors on residence within the nation's metropolitan area's suburban inner and outer rings. The results both confirm and contradict the main tenets of the spatial assimilation model. To the extent that income, education, and homeownership are positively related to residence in both suburban rings, the findings also suggest that access to inner and outer rings is hierarchically stratified by race and ethnicity.
\end{abstract}

Keywords: suburbs; locational attainment; spatial assimilation; race and ethnicity

\section{Introduction}

A common theme that is echoed in racial and ethnic locational attainment studies is that residence in the suburbs is a function of socioeconomic status (SES) attainments (Alba et al. 1999; Alba and Nee 2003; Farrell 2016; Logan and Alba 1993; Logan et al. 1996). This process, as outlined by the spatial assimilation model, suggests that increments in racial and ethnic groups' income and educational levels translate into residence in higher income suburban neighborhoods with qualitatively more desirable resources (Alba and Nee 1997; Massey 1985; Massey and Mullan 1985). Residence in qualitatively more desirable suburbs can have a positive impact on one's socioeconomic well-being, socio-psychological outcomes, life chances, and overall quality of life (Coley et al. 2013; Evans et al. 2000; Sampson 2012; Schaefer-McDaniel 2009; Sampson et al. 2002). To the extent that suburbs have traditionally represented the quintessential type of residence, as epitomized in the "American Dream" throughout most of the twentieth century (Kneebone and Berube 2013), recent research, however, has questioned the presumed superiority of the suburbs, in terms of offering its residents qualitatively more desirable amenities, resources, and opportunities relative to those that are found in central-cities (Anacker 2015a; Gallagher 2013; Hanlon 2010; Kneebone and Berube 2013).

A series of sociodemographic, economic, and structural intersecting processes since the late twentieth century have shaped and altered the composition of suburbs in the twenty-first century (Allard 2017; Anacker 2015a). As a result, suburbs are "no longer places with high proportions of home-owning non-Hispanic whites and native born with relatively high household incomes, high levels of education, and without any problems" (Anacker 2015b, p. 1). In addition to the increase in population size, the suburbs have become more diverse in terms of race, ethnicity, immigration, and citizenship status (Frey 2015). For the first time, the 2010 decennial census revealed that the majority of blacks, Asians, and Hispanics in the United States (U.S.) resided in the suburbs, as well 
as the majority of the foreign-born in the nation's top 100 largest metropolitan areas lived in their respective suburbs as well (Frey 2015; Wilson and Singer 2011). Along with increasing crime rates and a deteriorating and aging housing stock, the first two decades of the twenty-first century also reveals that the number of poor residents living in the suburbs has surpassed those living in central-cities ${ }^{1}$ (Allard 2017; Kneebone and Berube 2013).

To the extent that socioeconomic and structural changes have altered the compositional background of suburbia as a whole, a key feature of such changes pertains to differences between suburbs closer to the central-city (inner rings) and outer suburban rings (Hudnut 2003; Lucy and Phillips 2006; Anacker 2015a; Hanlon 2010; Short et al. 2007). Since the 1990s, inner suburban rings are more likely to have experienced significant increases in poverty (Hanlon and Vicino 2007; Green Leigh and Lee 2005), declining income levels (Holliday and Dwyer 2009), population fluctuations (Green Leigh and Lee 2005), increasing rates of income segregation (Swanstrom et al. 2004), and a rising share of an aging housing stock relative to their outer-ring counterparts (Lee and Leigh 2007; Hanlon 2010; Puentes and Orfield 2002). Housing market dynamics, labor market restructuring, and metropolitan political fragmentation also add to the list of forces shaping changes within suburbia and further solidifying the socioeconomic bifurcation between suburbia's inner and outer rings (Hanlon 2010). The above changes challenge the main tenets of the spatial assimilation model, in terms of its ability to describe the process by which racial and ethnic groups translate their SES levels into residence between suburban inner and outer rings.

The study's main goal is to examine racial and ethnic group differences in suburban attainment outcomes between their inner and outer rings residing within the nation's metropolitan areas. Using up-to-date individual-level data, the study adds to the literature on racial and ethnic group locational attainment outcomes by re-evaluating the applicability of the spatial assimilation model in relation to its key component, i.e., residence in the suburbs. While the spatial assimilation model has successfully described the process by which racial and ethnic groups translate their SES background characteristics into suburban outcomes throughout most of the twentieth century (Alba and Nee 2003), less is known, however, on the extent to which the model can accurately describe process by which groups residentially settle between suburbia's inner and outer rings.

\section{Theoretical Background \& Hypotheses}

The spatial assimilation model has traditionally served as the main theoretical model that is used to describe the relationship between racial and ethnic groups' SES attainment levels and suburban outcomes (Logan and Alba 1993; Alba and Logan 1993). Having its origins from the assimilation theories of Gordon (1964), the spatial assimilation model links residential mobility with elements of status attainment theory in order explain the process by which racial and ethnic group members attain residence in suburban neighborhoods, especially those with higher income levels and where the majority group, i.e., non-Hispanics, reside (Massey 1985; Massey and Mullan 1985). The model suggests that residence in qualitatively more desirable suburban locations is a function of a group's individual-level SES levels, and acculturation characteristics (Logan and Alba 1993; Alba and Nee 2003; Massey and Mullan 1985).

On average, the spatial assimilation model has successfully explained the relationship between SES attainments, acculturation characteristics, and suburban outcomes for the majority of white, Asian, and to a lesser extent, for Hispanic households (Alba and Nee 2003; Rosenbaum and Friedman 2007; Logan et al. 1996; Woldoff 2008). Household income and educational levels, including length of time spent in the U.S. and English language fluency levels, are positively related to residence in mostly white, suburban, high-income neighborhoods (Alba and Nee 2003; Rosenbaum and Friedman 2007). On the other hand, the spatial assimilation model fails to predict blacks' suburban outcomes relative to

1 Nevertheless, poverty rates in the suburbs continue to remain lower than their central-city counterparts (Allard 2017). 
whites, which are more likely to reside in lower quality neighborhoods and poorer suburbs relative to whites, even when controlling for SES (Alba and Logan 1991, 1993; Charles 2003; Rosenbaum 1996).

While traditional applications of the spatial assimilation model have examined the process by which groups (minorities or immigrants) move from central-cities to suburbs, in the present study, however, the model is used to describe the process by which groups attain a suburban outcome within its inner or outer rings. As stated earlier, socioeconomic, demographic, and structural changes within suburbia pose challenges to the spatial assimilation model's key outcome, i.e., residence in suburban locations. In addition to increasing poverty and crime rates, inner suburban rings also are experiencing rapid population growth and diversity in terms of race, ethnicity, and immigration as compared to their outer ring counterparts. Inner suburban rings also have a higher share older and aging housing stock built during the 1950s and 1960s, relative to the newer housing developments, as found in the outer-suburban rings (Hanlon 2010; Puentes and Orfield 2002). To the extent that outer suburban rings have higher income levels and they are in a better position to offer qualitatively more desirable resources and opportunities to its residents (Anacker 2015b), the spatial assimilation model suggests that residence in such neighborhoods is a function of each racial and ethnic group's SES, and acculturation, characteristics. Therefore, it hypothesized that differences in each racial and ethnic group's ability to convert their individual-level SES characteristics into residence in suburban outer rings relative to their inner ring counterparts is expected to decrease or disappear once controlling for SES, and the remaining theoretically relevant variables. To the extent that differences remain, it is expected that white, Asian, and to a lesser extent, Hispanic, households, to be more likely to reside in the outer-rings than black households, even when controlling for SES levels.

The spatial assimilation model's applicability to blacks has been questioned due to the persistent significance of the black race in U.S. society (Alba and Nee 2003; Charles 2003; Friedman and Rosenbaum 2005; Rosenbaum and Friedman 2007; Sharkey 2013; Wilkes and Iceland 2004). Race appears to be the most prominent factor relegating blacks to lower quality suburban neighborhoods as compared to other racial/ethnic groups. It appears that, for blacks, the penalty of race supersedes other factors that are highly valued in U.S. society, such as education. It should be mentioned though that when education does play a role for blacks' entrance into higher quality suburban neighborhoods, it does so in a way in which they have to climb a higher wall (once they are allowed to climb it in the first place) in order to reside in neighborhoods proportionate to their SES levels (Adelman et al. 2001; Logan and Alba 1993; Logan et al. 1996; Rosenbaum and Friedman 2007). On the other hand, there is the possibility that black households' likelihood of residing in the outer suburban rings will be, at minimum, similar to those of other racial and ethnic groups, as suggested by the housing availability model (Pfeiffer 2016).

The housing availability model provides clues on the processes by which black households translate their SES levels into residence in the outer suburban rings (South and Crowder 1998; Pfeiffer 2012, 2016). Borrowing elements from the spatial assimilation model and ecological aspects of the broader metropolitan area, the housing availability model suggests that the likelihood of residing in the outer suburban rings among black and other non-white groups might be higher following the passage of the 1968 Fair Housing Act. Declines in housing discrimination for housing built in the outer ring suburbs following the enactment of Fair Housing Act, along with the increase in white group tolerance to residing in neighborhoods with a higher share of nonwhites, has significantly minimized the barriers to which non-white groups, especially black households, encounter as they seek to translate their SES levels into residence in such places (Pfeiffer 2016). To the extent that residential segregation indices provide a general overview of the degree of social and spatial distance between racial and ethnic groups, then minorities may face weaker barriers to residential proximity with majority group members in outer-suburban rings than in inner-suburban rings and central cities (Anacker et al. 2017). Anacker et al. (2017) found that white-black residential segregation, as evinced by the index of dissimilarity, was lower in outer-suburban rings, i.e., those suburbs where the majority of housing was built after 1970, than their inner-ring counterparts, i.e., where the majority of suburban 
housing was built before 1970, including central-cities. This suggests a growing tolerance for racial and ethnic diversity in the former than the latter two locations, "where competition is intense, racial segregation patterns are entrenched, and poorer communities nearby" (Pfeiffer 2016, p. 801). Therefore, the housing availability model suggests that white and non-white household differences in the likelihood of residing in the outer-suburban rings will be smaller than those in suburban inner-rings, net of differences in SES, acculturation characteristics, and the remaining theoretically relevant variables.

Previous research reveals mixed results on the degree to which the housing availability model can describe black suburbanization outcomes in the outer versus the inner rings. Consistent with the model, Pfeiffer (2016) finds that non-white groups, e.g., African-Americans, residing in suburban neighborhoods where its housing was built after the Fair Housing Act experienced better neighborhood conditions and greater racial equity, than those residing in central cities and inner-suburban rings. In a case study of the Los Angeles region, the same author finds limited support for the housing availability model in that differences in neighborhoods conditions among racial groups with similar income is smaller among those residing in the outer-suburban rings of the Los Angeles metropolitan area than those residing in the inner city or its nearby suburbs (Pfeiffer 2012). While not focusing on the residential attainment differences between inner and outer suburban rings, Timberlake et al. (2011), however, find that the impact of housing growth on blacks' suburbanization was the weakest relative to the effect on whites, Asians, and Hispanics. Therefore, it appears that, for blacks and other darker skin groups, the penalty of race supersedes other factors that are highly valued in U.S. society, such as education and income (Charles 2003).

The place stratification model posits that race, prejudice and other forms of institutional discrimination, such as actions by the real estate and mortgage lending industries, appear to be the dominant force behind the suburban attainment patterns for specific non-white groups, especially for blacks and black Hispanics, net of differences in socioeconomic status (Alba and Logan 1993; Logan and Molotch 1987). According to this model, racial/ethnic groups and places are hierarchically ordered where the most advantaged group, i.e., whites seeks to distance themselves from less advantaged groups, i.e., non-whites (Logan and Molotch 1987). The ways in which majority group members distance themselves is manifested in the various individual or institutional acts of discrimination towards prospective minority homeseekers or renters, such as the negative treatment from financial lending institutions, landlords, real estate agents, and actions of neighborhood associations that seek to exclude minorities from buying homes in predominantly white neighborhoods (Yinger 1995). Although the 1968 Fair Housing Act essentially eliminated overt acts of housing discrimination on the basis of race and ethnicity; nonetheless, such acts have become subtler, whose effect is to channel minority households to lower quality neighborhoods (Turner et al. 2002).

Blacks and Hispanics are more likely to encounter discrimination, relative to comparable whites, during the entire housing transaction process, such as being denied information about the availability of houses or apartments, the opportunity to inspect housing units, the lack of assistance with mortgage financing from real estate agents, as well as being geographically steered towards certain neighborhoods, especially those with a larger share of Hispanics and blacks (Turner and Ross 2005, p. 86; Turner et al. 2013). On average, the most common causes of subtle forms of discrimination against minority households are real estate agents' and white customers' prejudice, which serve to channel minorities to predominantly non-white neighborhoods (Oh and Yinger 2015; Rothstein 2017). All of the above actions serve to produce suburban outcomes that vary by racial and ethnic origin. Non-Hispanic whites, on average, have the highest probability of residing in the suburbs followed by non-Hispanic Asians, Hispanics, and non-Hispanic blacks, even when controlling for differences in SES and acculturation status (Alba and Logan 1991; Alba and Logan 1993; Charles 2003; Logan and Alba 1993; Rosenbaum 1996). Accordingly, it is expected that racial and ethnic differences in the odds of residing in the outer-suburban rings (versus inner-rings) will continue to remain, even 
in the presence of controls for SES, acculturation characteristics, family/household status, and the region of where each group resides

\section{Data and Methods}

The main data source used is a five-year 2012-2016 American Community Survey (ACS) sample extracted from the Integrated Public Use Microdata Series (IPUMS) (Steven Ruggles et al. 2018). Contrary to aggregate-level data of the decennial census, the ACS consists of individual-level socioeconomic, demographic, and family/household data for various racial and ethnic groups in the U.S. Despite the dataset's limitations, such as its cross-sectional nature, its inability to account for undocumented immigrants (Capps et al. 2018), and undercount of certain racial and ethnic groups, such as blacks (U.S. Census Bureau 2012), the ACS has been widely used in past and present research investigating racial and ethnic group locational attainment outcomes (Alba and Logan 1991, 1993; Farrell and Firebaugh 2016; Crowell and Fossett 2018; Walker 2017). The sample ${ }^{2}$ is limited to non-Hispanic white, non-Hispanic black, non-Hispanic Asian, ${ }^{3}$ and Hispanic head of households ${ }^{4}$ who are between 25 and 64 years old. Following previous research, each racial and ethnic group is limited to 10,000 cases to avoid differences in group size from influencing the results (Logan and Alba 1993; Alba and Logan 1993).

The dependent variable differentiates between a suburb's inner and outer rings. ${ }^{5}$ Following Anacker et al. (2017) and Hanlon (2010), the year in which each housing structure was built is used to identify each respective suburban ring. The first stage in creating the dependent variable involves identifying households located in a non-metropolitan or metropolitan area, followed by distinguishing the latter category between those residing inside or outside the metropolitan area's central city. ${ }^{6}$ This resulted in the creation of the familiar central-city/outside of central city, i.e., suburbs, dichotomy variable, which has been extensively used in locational attainment research (Massey and Denton 1988; Frey and Speare 1988; Friedman and Rosenbaum 2005). ${ }^{7}$ The sample is then restricted to only suburban locations. The second stage differentiates between suburban inner and outer rings. Inner suburban rings are defined as those where the majority of housing was built in 1969 or earlier, and outer suburban rings as those whose housing was built in 1970 or later (Anacker et al. 2017; Hanlon 2009; Lucy and Phillips 2000, 2006).

The predictors are similar to those that were used in previous studies and are grouped into four categories, namely socioeconomic status (SES), acculturation, family/household status, and the region of where each group resides (Alba and Logan 1991; Logan and Alba 1993; Rosenbaum and Friedman 2004). The variables used to tap into the measurement of SES are: household income,

2 The group quarter population, which includes the institutionalized population residing in places such as dormitories, military, or other group living arrangements, are excluded.

3 Hereafter referred to as "white", "black", "Asian", unless otherwise noted.

4 The process of choosing where to live entails a complex set of decisions on behalf of households, which evolve around their preferences, needs, socioeconomic status, and other family/household characteristics, such as marital status, the presence of young children, and the presence of multiple members in the household or not. However, it is the head-of-the-householder's characteristics that will influence how they are treated in the housing market, and which will eventually determine the household's housing outcome (Rosenbaum and Friedman 2007).

5 While other labels have been used to describe such locations, e.g., mature and developed suburbs, the issues they face remain the same (Anacker 2015a).

6 Metropolitan area definitions vary by each decennial census, due to population and boundary shifts. As a result, there is an inevitable loss of geographic area, especially those areas not identifiable or not located within a metropolitan statistical area. Only those individuals located within a designated metropolitan area and residing outside central cities (henceforth referred to as "suburb") are included in the analysis.

7 Identifying suburban locations in such a manner, however, raises two limitations. Firstly, suburban locations with fewer than 100,000 inhabitants are not identifiable, due to the Census Bureau's confidentiality rules with respect to PUMS data (Alba and Logan 1991). As a result, places outside of a metropolitan area's central cities with less than the allowed population threshold are impossible to identify. Second, rural areas outside of central cities are impossible to exclude from the present dataset, again due to the Census Bureau's confidentiality limits to PUMS data. Despite these limitations, however, outside central city (suburban)/central-city distinction has been widely used in past and current racial/ethnic locational attainment research (Alba and Logan 1991,1993; Alba and Nee 2003; Alba et al. 2000). 
an ordinal variable measuring income in increments of $\$ 20,000$, and educational attainment, measuring respondents' highest completed school grade level ranging from "less than high school diploma" to "college degree or more". Homeownership is also included as a proxy for wealth (Alba et al. 1999; Logan and Alba 1993; Woldoff 2008). Acculturation is measured by English language proficiency level and length of time spent in the U.S. (Alba and Nee 2003).

The final set of indicators measure family/household status and the region of where each racial and ethnic group resides. Although the influence of family/household characteristics are not directly related to the spatial assimilation model, previous research document their importance in residential, and housing, attainment models (Logan and Alba 1993; Friedman and Rosenbaum 2005; South et al. 2005; South and Crowder 1997). For example, changes in family/household characteristics, such as its composition, size, and structure can influence a household's locational outcome (Rossi 1955; South and Deane 1993). Important life-cycle changes, such as graduating from college, marriage, employment, and the arrival of children can also increase, or influence, a household's probability of moving to a larger housing unit that meets their preferences and needs, either in the same region or a different state/city location (South and Crowder 1997). Six predictors measure family/household characteristics: householder's sex, marital status, presence of own family members in the household, age, the presence of own children under age 18, and household size. The variable "region" takes into consideration each racial and ethnic group's regional concentration.

The data analyses consist of two parts: bivariate and multivariate. The bivariate analyses explore the background characteristics of the racial and ethnic groups of interest. ${ }^{8}$ The multivariate segment consists of calculating a series of logistic regression equations in order to determine which predictors are more likely to predict each racial and ethnic group's residence in outer versus inner suburban rings. Logistic regression is the most preferred statistical multivariate method to use when the dependent variable is dichotomous (Tabachnick and Fidell 2001). All categorical predictors are dummy coded, tested for multicollinearity, and standardized. For ease of interpretation, the standardized odds ratios are presented, which indicate the change in the odds of residing in the outer versus inner suburban rings for each standard deviation change in the associated predictors.

\section{Results}

Table 1 presents the descriptive results of white, black, Asian, and Hispanic households' individual-level background characteristics. Due to space limitations, we only focus on the results pertaining to SES and acculturation characteristics. The results reveal two main findings. First, all racial and ethnic groups are more likely to reside in the outer suburban rings than their inner ring counterparts. Second, differences between the groups of interest reveal a racial and ethnic hierarchy, whereby Asians have higher shares of their households residing in the outer suburban rings, followed by those of black, Hispanic, and white households.

To the extent that the spatial assimilation theory predicts that suburban residence is linked to higher levels of individual-level socioeconomic attainments, we expect a similar pattern with respect to residence in the outer suburban rings. The results in Table 1 confirm this expectation in that all racial and ethnic group households have high educational attainment levels, i.e., have earned a college degree or higher, nearly a quarter of each group's household have household incomes over $\$ 100,000$, and more likely to be homeowners. Meanwhile, differences between the groups reveal that white and Asian households are more likely to have higher median household income, educational, and homeownership levels than their respective black and Hispanic household counterparts. In addition, the findings also reveal that Asian households have higher median household income and educational levels than white households. While black households are more likely to have lower median household income level than Hispanics, the former group is, however, more likely to have a higher share of

8 Tukey's B post hoc tests are computed to assess statistical significance in group differences on the variables of interest. 
households with some college or with a college degree or higher than the latter group. With respect to homeownership, white households are more likely to own their housing units, followed by Asian, Hispanic, and black households.

Table 1. Selected Descriptive Characteristics of White, Black, Asian, and Hispanic Households.

\begin{tabular}{|c|c|c|c|c|}
\hline Suburb Type & White & Black & Asian & Hispanic \\
\hline Mature & $39.4^{b, c}$ & 36.3 & 27.3 & 38.1 \\
\hline Developing & $60.6^{b, c}$ & 63.7 & 72.7 & 61.9 \\
\hline \multicolumn{5}{|l|}{ Socioeconomic Status } \\
\hline \multicolumn{5}{|l|}{ Household Income } \\
\hline$\$ 0-\$ 19,999$ & $7.1^{b, d}$ & 17.3 & 6.2 & 12.6 \\
\hline$\$ 20,000-\$ 39,999$ & $10.4^{\mathrm{b}, \mathrm{d}}$ & $18.3^{a, c}$ & 9.4 & 19.4 \\
\hline$\$ 40,000-\$ 59,999$ & 13.1 & 16.4 & 10.7 & 18.4 \\
\hline$\$ 60,000-\$ 79,999$ & $13.4^{\mathrm{c}}$ & $13.4^{\mathrm{d}}$ & 11.3 & 14.0 \\
\hline$\$ 80,000-\$ 99,999$ & 12.9 & $10.4^{\mathrm{a}}$ & $10.6^{\mathrm{a}, \mathrm{b}}$ & 10.0 \\
\hline$\$ 100,000-\$ 119,000$ & $10.1^{b, d}$ & $7.5^{\mathrm{a}, \mathrm{c}}$ & 10.2 & 7.7 \\
\hline$\$ 120,000$ and up & 33.0 & $16.8^{a, c}$ & 41.6 & 18.0 \\
\hline Median Total Household Income & $\$ 88,905$ & $\$ 56,988$ & $\$ 102,394$ & $\$ 59,351$ \\
\hline \multicolumn{5}{|l|}{ Education of householder } \\
\hline Less than High School Diploma & 3.7 & 7.3 & 6.1 & 22.0 \\
\hline High School Diploma & 21.4 & $23.0^{a, c}$ & 9.9 & 23.8 \\
\hline Some College & $30.1^{b, c}$ & 37.6 & 17.3 & 29.2 \\
\hline College Degree or More & 44.8 & 32.1 & 66.8 & 25.0 \\
\hline Homeownership & 79.5 & 52.9 & 73.3 & 57.3 \\
\hline \multicolumn{5}{|l|}{ Acculturation } \\
\hline \multicolumn{5}{|l|}{ Years in the United States } \\
\hline $0-5$ years & $6.4^{\mathrm{c}}$ & $6.5^{\mathrm{a}, \mathrm{c}}$ & 9.6 & 5.2 \\
\hline $6-10$ years & $7.1^{d}$ & $11.8^{\mathrm{a}, \mathrm{d}}$ & 11.3 & 8.9 \\
\hline $11-15$ years & $10.6^{b, d}$ & $15.9^{\mathrm{a}}$ & 13.9 & 15.9 \\
\hline $16-20$ years & 14.4 & $14.9^{\mathrm{a}}$ & $14.2^{\mathrm{a}, \mathrm{b}}$ & 14.2 \\
\hline $21+$ years & 61.5 & $50.9^{\mathrm{a}, \mathrm{d}}$ & 51.0 & 55.8 \\
\hline \multicolumn{5}{|l|}{ English Language Ability } \\
\hline Speaks English only & 94.7 & 89.2 & 20.3 & 23.4 \\
\hline Speaks English very well or well & 4.9 & 10.0 & 70.2 & 57.8 \\
\hline Speaks English not well or not at all & $0.4^{\mathrm{c}, \mathrm{d}}$ & 0.8 & 9.5 & 18.8 \\
\hline \multicolumn{5}{|l|}{ Family/Household Status } \\
\hline \multicolumn{5}{|l|}{ Nativity Status } \\
\hline Native Born & 94.5 & 81.9 & 14.7 & 40.9 \\
\hline \multicolumn{5}{|l|}{ Sex } \\
\hline Male & 53.0 & 38.7 & 63.8 & 50.7 \\
\hline Female & 47.0 & 61.3 & 36.2 & 49.3 \\
\hline \multicolumn{5}{|l|}{ Marital Status } \\
\hline Married & 64.9 & 40.1 & 76.8 & 60.2 \\
\hline Never Married & 14.9 & 30.9 & 12.5 & 18.2 \\
\hline Others & $20.2^{b, c}$ & 29.0 & 10.8 & 21.6 \\
\hline \multicolumn{5}{|l|}{ Number of Families in Household } \\
\hline 1 Family & $96.5^{b, d}$ & $95.7^{\mathrm{a}, \mathrm{d}}$ & 95.8 & 93.7 \\
\hline 1+ Family & $3.5 \mathrm{c}$ & $4.3^{\mathrm{a}, \mathrm{d}}$ & 4.2 & 6.4 \\
\hline \multicolumn{5}{|l|}{ Age of Householder } \\
\hline $25-34$ & 14.2 & $16.22^{a, d}$ & 17.5 & 20.6 \\
\hline $35-44$ & 21.7 & 23.6 & 31.0 & 29.2 \\
\hline $45-54$ & $30.8^{\mathrm{c}, \mathrm{d}}$ & $30.4^{\mathrm{a}, \mathrm{c}}$ & $28.3^{a, b}$ & 29.1 \\
\hline $55-64$ & 33.4 & 29.8 & 23.2 & 21.1 \\
\hline \multicolumn{5}{|l|}{ Children Under 18 Present in Household } \\
\hline No Children Present $<18$ & $82.4^{b, d}$ & 76.2 & 83.7 & 73.6 \\
\hline Children Present $<18$ & $17.6^{\mathrm{b}, \mathrm{d}}$ & 23.8 & 16.3 & 26.4 \\
\hline
\end{tabular}


Table 1. Cont

\begin{tabular}{|c|c|c|c|c|}
\hline Suburb Type & White & Black & Asian & Hispanic \\
\hline \multicolumn{5}{|l|}{ Household Size } \\
\hline 1-2 Persons & $51.7^{\mathrm{c}, \mathrm{d}}$ & 52.8 & $32.9^{a, b}$ & 32.2 \\
\hline 3-4 Persons & 37.1 & 34.3 & 49.2 & 44.0 \\
\hline 4+ Persons & 11.1 & 12.9 & 17.9 & 23.8 \\
\hline \multicolumn{5}{|l|}{ Region } \\
\hline Northeast & 38.2 & $21.4^{\mathrm{a}, \mathrm{c}}$ & 32.2 & 20.8 \\
\hline Midwest & 22.1 & 16.0 & 9.7 & 7.2 \\
\hline South & 26.8 & 54.1 & 23.4 & 38.3 \\
\hline West & 12.8 & 8.6 & $34.8^{\mathrm{a}, \mathrm{b}}$ & 33.7 \\
\hline $\mathrm{N}$ & 10,000 & 10,000 & 10,000 & 10,000 \\
\hline
\end{tabular}

Source: 2012-2016 American Community Survey (ACS); a Statistically significant with whites, $p<0.05$; b Statistically significant with blacks, $p<0.05$; c Statistically significant with Asians, $p<0.05$; d Statistically significant with Hispanics, $p<0.05$.

The findings in Table 1 also reveal four main findings with respect to differences in acculturation. First, Asian, Hispanic, and black households have a higher share of foreign-born households than whites. Second, over half of each group's foreign-born households have been residing in the U.S. for over twenty years. Third, Asians and blacks have higher shares of recently arrived foreign-born households when compared to the other two groups' households. Lastly, and with respect to English language fluency, all groups have relatively high English language proficiency levels.

In addition to SES differences between the groups of interest, the results also reveal differences in the SES characteristics of the suburban ring of where each group resides. Overall, white and Asian households are more likely to reside in both outer and inner suburban rings with higher SES levels and lower poverty rates relative to those where black and Hispanic households reside (see Table 2).

Table 2. Selected Mature and Developing Suburban Characteristics of Where Each Group Resides.

\begin{tabular}{|c|c|c|c|c|}
\hline & White & Black & Asian & Hispanic \\
\hline \multicolumn{5}{|l|}{ Mature Suburbs } \\
\hline Median Houehold Income & $\$ 80,000$ & $\$ 50,690$ & $\$ 96,402$ & $\$ 59,033$ \\
\hline Percent College Degree or More & 41.9 & 26.0 & 60.5 & 21.6 \\
\hline Percent Owned Housing Units & 76.9 & 49.4 & 70.4 & 55.0 \\
\hline FB Percent & 5.3 & 19.4 & 83.6 & 59.5 \\
\hline $\begin{array}{l}\text { Percent Below } 100 \text { percent } \\
\text { Poverty }\end{array}$ & $7.4^{\mathrm{b}, \mathrm{d}}$ & 19.2 & 7.9 & 15.9 \\
\hline \multicolumn{5}{|l|}{ Developing Suburbs } \\
\hline Median Houehold Income & $\$ 94,682$ & $\$ 60,828^{a, c}$ & $\$ 104,536$ & $\$ 59,593$ \\
\hline Percent College Degree or More & 46.7 & 35.6 & 69.1 & 27.1 \\
\hline Percent Owned Housing Units & 81.1 & 54.9 & 74.5 & 58.7 \\
\hline FB Percent & 5.6 & 17.4 & 86.0 & 58.8 \\
\hline $\begin{array}{l}\text { Percent Below } 100 \text { percent } \\
\text { Poverty }\end{array}$ & $5.8^{\mathrm{b}, \mathrm{d}}$ & $14.3^{\mathrm{a}, \mathrm{c}}$ & 6.0 & 15.0 \\
\hline $\mathrm{N}$ & \multicolumn{4}{|c|}{10,000} \\
\hline
\end{tabular}

Source: 2012-2016 American Community Survey (ACS); ${ }^{\text {a }}$ Statistically significant with whites, $p<0.05$; $^{\text {b }}$ Statistically significant with blacks, $p<0.05$; ${ }^{\mathrm{c}}$ Statistically significant with Asians, $p<0.05$; ${ }^{\mathrm{d}}$ Statistically significant with Hispanics, $p<0.05$.

The finding that Asian and Hispanic households reside in both inner and outer suburban rings with higher shares of foreign-bon than the other two groups tentatively hint to the possibility that that they are able to bypass central cities and directly reside in suburban immigrant ethnic enclaves (Alba and Nee 1997, 2003). These ethnic enclaves allow for Asian and Hispanic immigrants with modest economic means and limited English levels to reside in suburban communities (Alba et al. 1999; Charles 2006; Logan et al. 2002). 
To the extent that the aforementioned SES advantages exhibited by white and Asian households relative to their black and Hispanic counterparts will explain the descriptive differences, as revealed in Table 1, what remains to be seen is if there are differences in the rate at which each group translates their individual-level SES achievements into residence in outer versus inner suburban rings. The multivariate results will also test the degree to which these descriptive differences in the type of suburban residence can be explained by differences in race and ethnicity, SES, acculturation characteristics, and the remaining theoretically relevant predictors.

Table 3 presents the pooled, sequential, and logistic regression models that estimate the effects of each predictor on the odds of residing in the outer suburban rings versus their inner ring counterparts. Model I controls only for race and ethnicity. Model II adds SES, i.e., household income, occupation, education, and homeownership, and Model III incorporates acculturation characteristics, i.e., length of time spent in the U.S. and English language proficiency levels. The last two models, IV and V add family/household status and the region of where each racial and ethnic group resides, respectively. All results are presented as odds ratios to facilitate interpretation ${ }^{9}$.

Table 3. Pooled Binary Logisitic Regression Results Predicting Developing (vs. Mature) Suburban Outcomes (vs. Mature)-Standardized Odds Ratios.

\begin{tabular}{|c|c|c|c|c|c|}
\hline & $\begin{array}{l}\text { Model } \\
\text { I }\end{array}$ & $\begin{array}{l}\text { Model } \\
\text { II }\end{array}$ & $\begin{array}{c}\text { Model } \\
\text { III }\end{array}$ & $\begin{array}{l}\text { Model } \\
\text { IV }\end{array}$ & $\begin{array}{c}\text { Model } \\
\text { V }\end{array}$ \\
\hline \multicolumn{6}{|l|}{ Racial and Ethnic Group (ref. = White) } \\
\hline Black & $1.058 *$ & $1.102 *$ & $1.101 *$ & $1.124 *$ & $0.936^{*}$ \\
\hline Asian & $1.267 *$ & $1.241^{*}$ & $1.221 *$ & $1.218^{*}$ & $1.164^{*}$ \\
\hline Hispanic & $1.023 *$ & $1.090 *$ & $1.088^{*}$ & $1.089 *$ & $0.935 *$ \\
\hline \multicolumn{6}{|l|}{ Socioeconomic Status } \\
\hline \multicolumn{6}{|l|}{ Household Income (ref. $=\$ 120,000$ and up) } \\
\hline$\$ 0-\$ 19,999$ & & $0.943 *$ & $0.942 *$ & $0.955 *$ & $0.904 *$ \\
\hline$\$ 20,000-\$ 39,999$ & & $0.971 *$ & $0.968 *$ & $0.974 * *$ & $0.910 *$ \\
\hline$\$ 40,000-\$ 59,999$ & & $0.934 *$ & $0.932 *$ & $0.937 *$ & $0.882 *$ \\
\hline$\$ 60,000-\$ 79,999$ & & $0.972 *$ & $0.970 *$ & $0.972 *$ & $0.928 *$ \\
\hline$\$ 80,000-\$ 99,999$ & & 0.992 & 0.990 & 0.989 & $0.956^{*}$ \\
\hline$\$ 100,000-\$ 119,000$ & & 0.985 & 0.984 & 0.984 & $0.964 *$ \\
\hline \multicolumn{6}{|c|}{ Education of householder (ref. = College degree or more) } \\
\hline Less than High School Diploma & & $0.868 *$ & $0.884 *$ & $0.897 *$ & $0.879 *$ \\
\hline High School Diploma & & $0.869 *$ & $0.879 *$ & $0.888 *$ & $0.876^{*}$ \\
\hline Some College & & $0.937 *$ & $0.948 *$ & $0.955 *$ & $0.935 *$ \\
\hline Renter (vs. owner) & & $0.952 *$ & $0.934 *$ & $0.930 *$ & 0.989 \\
\hline \multicolumn{6}{|l|}{ Acculturation } \\
\hline \multicolumn{6}{|l|}{ Years in the United States (ref. = Native-Born) } \\
\hline $0-5$ years & & & $1.064 *$ & $1.047 *$ & $1.050 *$ \\
\hline $6-10$ years & & & $1.057 *$ & $1.042 *$ & $1.046^{*}$ \\
\hline $11-15$ years & & & 1.054 * & $1.042 *$ & $1.039 *$ \\
\hline $16-20$ years & & & 1.017 & 1.009 & 1.017 \\
\hline $21+$ years & & & 0.976 & 0.985 & 0.991 \\
\hline \multicolumn{6}{|c|}{ English Language Ability (ref. = Speak English Only) } \\
\hline Speaks English very well or well & & & 1.002 & 1.002 & 1.008 \\
\hline Speaks English not well or not at all & & & $0.959 *$ & $0.968 *$ & $0.956 *$ \\
\hline \multicolumn{6}{|l|}{ Family/Household Status } \\
\hline Sex (ref. = Male) & & & & 0.978 & $0.975^{* *}$ \\
\hline \multicolumn{6}{|l|}{ Age of householder (ref. = 35-44) } \\
\hline $25-34$ & & & & $1.025 * *$ & 1.018 \\
\hline $45-54$ & & & & $0.949 *$ & $0.963 *$ \\
\hline $55-64$ & & & & $0.902 *$ & $0.914 *$ \\
\hline \multicolumn{6}{|l|}{ Marital Status (ref. = Married) } \\
\hline Never Married & & & & $0.893 *$ & $0.913 *$ \\
\hline Others & & & & 0.980 & $0.971 *$ \\
\hline
\end{tabular}

9 The corresponding coefficients and standard errors for Table A1 can be found in Appendix A. 
Table 3. Cont.

\begin{tabular}{|c|c|c|c|c|c|}
\hline & $\begin{array}{l}\text { Model } \\
\text { I }\end{array}$ & $\begin{array}{c}\text { Model } \\
\text { II }\end{array}$ & $\begin{array}{c}\text { Model } \\
\text { III }\end{array}$ & $\begin{array}{l}\text { Model } \\
\text { IV }\end{array}$ & $\begin{array}{c}\text { Model } \\
\text { V }\end{array}$ \\
\hline \multicolumn{6}{|c|}{ Number of Families in Household (ref. = 1 Family) } \\
\hline $1+$ family & & & & $0.973 *$ & $0.955^{*}$ \\
\hline \multicolumn{6}{|c|}{ Number of persons in household (ref. $=1-2$ persons) } \\
\hline 3-4 Persons & & & & 0.979 & $0.970 *$ \\
\hline 4+ Persons & & & & $0.918 *$ & $0.911 *$ \\
\hline \multicolumn{6}{|c|}{ Children Under 18 Present in Household (ref. = Children $<18$ Present) } \\
\hline No Children Present $<18$ & & & & 1.009 & 0.997 \\
\hline \multicolumn{6}{|l|}{ Region (ref. = Northeast) } \\
\hline Midwest & & & & & $1.242 *$ \\
\hline South & & & & & $2.429 *$ \\
\hline West & & & & & $1.598^{*}$ \\
\hline $\mathrm{N}$ & & & 10,000 & & \\
\hline Nagelkerke R Square & 0.014 & 0.027 & 0.030 & 0.036 & 0.172 \\
\hline
\end{tabular}

Two main findings emerge from the pooled results, as revealed in Table 3. The first finding is really a set of findings. Racial and ethnic group differences in the odds of residing in the outer (versus inner) ring suburbs remain, even when controlling for the effects of the theoretically relevant predictors. Specifically, all nonwhite groups have higher odds of residing in the outer suburban rings than white households, net of differences in SES, acculturation, and family/household characteristics (see models I-IV). With respect to differences between the groups the results reveal that Asian households are more likely to reside in the outer suburban rings than white, black, and Hispanic households. For example, Asian households' odds of residing in outer rings suburbs are between $22 \%$ and $27 \%$ higher than the odds that are associated to black and Hispanic households, which are between $6 \%-12 \%$ and $2 \%-9 \%$, respectively, even when controlling for the effects of race/ethnicity, SES, acculturation, and family/household characteristics separately or jointly (see Models I-IV).

The second main finding pertains to the effect of "region". The odds of each racial and ethnic group's residence in the outer (versus inner) suburban rings change direction when adding region to the set of predictors, as revealed in Model V. As a result, Asian households continue to remain more likely to reside in the outer suburban rings than white, black, and Hispanic households. The aforementioned changes, as produced by adding region to the set of predictors, possibly taps into metropolitan (structural) factors that may either hinder or enhance each group's ability to reside in the outer suburban rings. Features of the metropolitan region, such residential segregation, population density, labor market structure, poverty rates, and availability of affordable housing are all factors that can serve to stratify racial and ethnic group's residential outcomes in suburbia, as described by the place stratification model (Logan and Alba 1991; Hanlon 2010).

To the extent that the above pooled results illustrate the importance of race and ethnicity, estimating the models for each group separately provides us with more detail concerning the nuances that are involved in each group's likelihood of residing in the outer versus inner suburban rings. Table 4 presents the results from the individual level models for each racial and ethnic group of interest. ${ }^{10}$ Reflecting the pooled models in Table 3, the findings continue to reveal mixed results to the expectations as outlined by the spatial assimilation model.

On average, SES exerts a positive relationship in residing in the outer suburban rings for the majority of the racial and ethnic groups of interest. With the exception of Hispanics, all of the other groups' income levels are positively related to the odds of residing in the outer suburban rings, relative to their inner ring counterparts. While the effect of education is also positively related to residence in the outer suburban rings, Table 4 reveals that white households with less than a high school diploma

10 The corresponding coefficients and standard errors for Table A2 can be found in Appendix A. 
and those who have attended some college are no more likely than their higher educated counterparts to reside in the outer suburban rings. Hispanic households with some college are also no more likely to reside in the outer suburban rings than their counterparts with a college degree or higher. As expected, the effect of the last SES indicator, tenure status, reveals that renter households are less likely to reside in the outer rings than their respective homeowner counterparts. However, black household renters are more likely to reside in the outer suburban rings as compared to the other groups.

Table 4. Group Specific Logisitic Regression Results Predicting Developing (vs. Mature) Suburban Outcomes-Standardized Odds Ratios.

\begin{tabular}{|c|c|c|c|c|}
\hline & White & Black & Asian & Hispanic \\
\hline \multicolumn{5}{|l|}{ Socioeconomic Status } \\
\hline \multicolumn{5}{|l|}{ Household Income (ref. $=\$ 120,000$ and up) } \\
\hline$\$ 0-\$ 19,999$ & $0.861 *$ & $0.849 *$ & $0.919 *$ & 0.995 \\
\hline$\$ 20,000-\$ 39,999$ & $0.855 *$ & $0.873 *$ & $0.936 *$ & 0.982 \\
\hline$\$ 40,000-\$ 59,999$ & $0.806 *$ & $0.842 *$ & $0.909 *$ & 0.987 \\
\hline$\$ 60,000-\$ 79,999$ & $0.901 *$ & $0.882 *$ & 0.972 & 0.985 \\
\hline$\$ 80,000-\$ 99,999$ & $0.930 *$ & $0.934 *$ & 1.003 & 0.976 \\
\hline$\$ 100,000-\$ 119,000$ & 0.987 & $0.939 *$ & $0.956 * *$ & 0.974 \\
\hline \multicolumn{5}{|c|}{ Education of householder (ref. = College degree or more) } \\
\hline Less than High School Diploma & 0.954 & $0.827 *$ & $0.862 *$ & $0.900 *$ \\
\hline High School Diploma & $0.942 *$ & $0.833 *$ & $0.878 *$ & $0.888 *$ \\
\hline Some College & 0.972 & $0.911 *$ & $0.899 *$ & 0.961 \\
\hline Renter (vs. owner) & $0.934 *$ & $1.044 * *$ & 0.924 * & 1.006 \\
\hline \multicolumn{5}{|l|}{ Acculturation } \\
\hline \multicolumn{5}{|l|}{ Years in the United States (ref. = Native-Born) } \\
\hline $0-5$ years & 0.970 & 0.999 & 1.056 * & $1.079 *$ \\
\hline $6-10$ years & 1.096 & 1.019 & $1.066 *$ & $1.043 * *$ \\
\hline $11-15$ years & 1.057 & 1.043 & 1.037 & $1.047 *$ \\
\hline 16-20 years & 1.015 & 0.960 & $1.055 *$ & 0.993 \\
\hline $21+$ years & 0.980 & 0.964 & 1.047 & 0.967 \\
\hline \multicolumn{5}{|c|}{ English Language Ability (ref. = Speak English Only) } \\
\hline Speaks English very well or well & 0.987 & $0.926 * *$ & $1.090 *$ & 0.957 \\
\hline Speaks English not well or not at all & 1.109 & 0.983 & 0.978 & $0.917 *$ \\
\hline \multicolumn{5}{|l|}{ Family/Household Status } \\
\hline Sex (ref. = Male) & 0.974 & 1.035 & $0.877 *$ & 1.004 \\
\hline \multicolumn{5}{|l|}{ Age of householder (ref. $=35-44$ ) } \\
\hline $25-34$ & 1.027 & 1.040 & 0.982 & 1.035 \\
\hline $45-54$ & $0.928 *$ & $0.943 *$ & $\begin{array}{c}0.946 \\
* * *\end{array}$ & 1.023 \\
\hline $55-64$ & $0.906 *$ & $0.901 *$ & $0.912 *$ & $0.937 *$ \\
\hline \multicolumn{5}{|l|}{ Marital Status (ref. = Married) } \\
\hline Never Married & $0.873^{*}$ & $0.944 *$ & $0.926 *$ & $0.902 *$ \\
\hline Others & 1.012 & 0.961 & 0.965 & 0.967 \\
\hline \multicolumn{5}{|c|}{ Number of Families in Household (ref. = 1 Family) } \\
\hline 1+ family & $0.907 *$ & 0.979 & $0.937 *$ & 0.986 \\
\hline \multicolumn{5}{|c|}{ Number of persons in household (ref. $=1-2$ persons) } \\
\hline 3-4 Persons & 1.019 & $0.947 * *$ & 0.958 & $0.926 *$ \\
\hline 4+ Persons & 0.981 & $0.911 *$ & 0.877 * & $0.895 *$ \\
\hline \multicolumn{5}{|c|}{ Children Under 18 Present in Household (ref. = Children $<18$ Present) } \\
\hline No Children Present $<18$ & 1.023 & 1.016 & 1.004 & 0.966 \\
\hline \multicolumn{5}{|l|}{ Region (ref. = Northeast) } \\
\hline Midwest & $1.245 *$ & $1.131 *$ & 1.498 * & $1.243 *$ \\
\hline South & $2.335 *$ & 2.398 * & 2.208 * & $2.675 *$ \\
\hline West & 1.808 * & 1.891 * & 1.516 * & $1.568 *$ \\
\hline $\mathrm{N}$ & & & 000 & \\
\hline Nagelkerke R Square & 0.172 & 0.205 & 0.127 & 0.183 \\
\hline
\end{tabular}

Source: 2012-2016 American Community Survey (ACS); ${ }^{*} p<0.05 ;{ }^{* *} p<0.10$ 
The results in Table 4 also provide tentative evidence to the notion that the returns to SES differ between the racial and ethnic groups of interest. While black households incur a greater loss to residing in the outer rings for all levels of income relative to those accrued by Asian households, the former group's losses, however, relative to whites present mixed results. With respect to education, black households incur a greater loss in the odds of residing in the outer suburban rings for every level of education when compared to white, Asian, and Hispanic households. This suggests that with each increment of educational attainment level, black households achieve a greater return in residing in the outer suburban rings compared to those accrued by the other groups. In other words, by virtue of white, Asian, and Hispanic households' higher odds of residing in the outer suburban rings for nearly every level of education, they all accrue smaller improvements in the odds of residing in such places with each increment in education relative to those that are accrued by black households. With respect to homeownership, black household renters have higher odds of residing in the outer suburban rings than their respective white, Asian, and Hispanic renter counterparts. Meanwhile, Hispanic households who rent are no more likely than their homeowner co-ethnics to reside in the outer suburban rings. Differences between white and Asian households are nearly similar.

The effects of acculturation also reveal contradictory results to the main tenets of the spatial assimilation model. Black and Asian households who do not speak English or those with limited English language proficiency levels are no more likely to reside in the outer suburban rings than their counterparts who speak English only (see Table 4). Interestingly, Asian households who speak English well or very well have higher odds of residing in the outer rings than their counterparts who speak English only. The effect among white households continues to reveal mixed results. For example, white households with limited English language fluency levels are no more likely than their counterparts who speak only English to reside in the outer suburban rings. With respect to length of time that is spent in the U.S., the results for white and black households are not statistically significant, as well as for some longer-term Asian arrivals, i.e., those residing in the U.S. between 11-15 and 20+ years. In contradiction to the spatial assimilation model, recently arrived Asian and Hispanic households, i.e., those residing in the U.S. less than ten years, have higher odds of residing in the outer suburban rings when compared to each group's native-born counterparts.

\section{Discussion}

The present study examined inner and outer suburban ring attainment outcomes among racial and ethnic groups residing in the nation's metropolitan areas. While the spatial assimilation model has relied on the 'central-city/suburb' dichotomy from which to measure the relationship between group SES and residential outcomes, sociodemographic, economic, and structural changes within suburbs since the late twentieth century, however, calls for the need to revisit the model's hypothesized predicted locational outcome. Therefore, the main objective was to re-evaluate the extent to which the spatial assimilation model can accurately describe the relationship between white, black, Asian, and Hispanic households' SES, and acculturation, characteristics with the odds of residing in the outer versus inner suburban rings.

Overall, both the bivariate and multivariate findings confirm and contradict the main tenets of the spatial assimilation model. While all groups are more likely to reside in outer suburban rings than their inner ring counterparts, a racial and ethnic hierarchy exists in that Asians have higher shares of their households residing in the outer rings, followed by black, Hispanic, and white households. Contrary to the spatial assimilation model, the multivariate models fail to minimize the racial and ethnic group differences in the odds of residing in outer suburban rings relative to their inner ring counterparts. Despite the positive relationship between all groups' SES attainments and the odds of residing in the outer suburban rings, the multivariate results also reveal that differences in the returns each group receives to each SES indicator varies by race and ethnicity. Another key finding relates to the effect of region. The finding that the addition of region reverses the direction of the odds of residing in the outer suburban rings for both black and Hispanic households relative to those of Asian and white 
households points to a critical difference in the process of seeking residence in the suburbs. This might suggest that the advantage certain racial and ethnic groups have in residing in either the outer or inner suburban rings lies in the ways of how they are perceived by institutional, and individual, housing agents during their encounter with the suburban housing market (Rothstein 2017).

While this is the first study to explore the relationship between racial and ethnic group's SES attainments and residential outcomes between suburban inner and outer rings, it is not without limitations. Future research should explore both the micro and macro level processes, at the regional level, of how each racial and ethnic group seeks to secure residence across inner and outer rings. Socioeconomic, demographic, and structural changes within suburbia also call for future research unpacking the nuances that are involved in the processes as racial and ethnic groups seek to convert their SES attainments into residence in neighborhoods across suburbia. Furthermore, the study can be improved by differentiating each racial and ethnic group by place of birth, generation, and/or national origin, so as to uncover underlying SES and acculturation differences within and between each group's likelihood of residing in either suburban ring. To the extent that the current findings are time contingent to the time period studied or can be replicated for other time periods, the present study raises the continued importance of race and SES in influencing racial and ethnic group's locational attainment outcomes within suburbia.

Funding: This research received no external funding.

Conflicts of Interest: The author declares no conflict of interest. 


\section{Appendix A}

Table A1. Pooled Binary Logisitic Regression Results Predicting Developing (vs. Mature) Suburban Outcomes-Standardized Coefficients (Standrd Errors).

\begin{tabular}{|c|c|c|c|c|c|}
\hline & Model I & Model II & Model III & Model IV & Model V \\
\hline \multicolumn{6}{|l|}{ Racial and Ethnic Group (ref. = White) } \\
\hline Black & $0.057 *(0.013)$ & $0.097 *(0.013)$ & $0.096 *(0.013)$ & $0.117 *(0.013)$ & $-0.066 *(0.015)$ \\
\hline Asian & $0.236 *(0.013)$ & $0.216 *(0.013)$ & $0.199 *(0.018)$ & $0.197 *(0.018)$ & $0.152 *(0.019)$ \\
\hline Hispanic & $0.023 *(0.013)$ & $0.086 *(0.013)$ & $0.085 *(0.016)$ & $0.085 *(0.016)$ & $-0.067 *(0.018)$ \\
\hline \multicolumn{6}{|l|}{ Socioeconomic Status } \\
\hline \multicolumn{6}{|l|}{ Household Income (ref. $=\$ 120,000$ and up) } \\
\hline$\$ 0-\$ 19,999$ & & $-0.058 *(0.013)$ & $-0.060 *(0.013)$ & $-0.046 *(0.014)$ & $-0.101 *(0.015)$ \\
\hline$\$ 20,000-\$ 39,999$ & & $-0.030 *(0.013)$ & $-0.033 *(0.014)$ & $-0.026 *(0.014)$ & $-0.094 *(0.015)$ \\
\hline$\$ 40,000-\$ 59,999$ & & $-0.068 *(0.013)$ & $-0.07 *(0.013)$ & $-0.065 *(0.013)$ & $-0.126 *(0.014)$ \\
\hline$\$ 60,000-\$ 79,999$ & & $-0.028 *(0.013)$ & $-0.031 *(0.013)$ & $-0.028 *(0.013)$ & $-0.074 *(0.014)$ \\
\hline$\$ 80,000-\$ 99,999$ & & $-0.008(0.012)$ & $-0.010(0.012)$ & $-0.011(0.012)$ & $-0.045 *(0.013)$ \\
\hline$\$ 100,000-\$ 119,000$ & & $-0.015(0.012)$ & $-0.016(0.012)$ & $-0.016(0.012)$ & $-0.037 *(0.013)$ \\
\hline \multicolumn{6}{|c|}{$\begin{array}{l}\text { Education of householder (ref. }=\text { College degree or } \\
\text { more) }\end{array}$} \\
\hline Less than High School Diploma & & $-0.141 *(0.012)$ & $-0.123 *(0.013)$ & $-0.108 *(0.013)$ & $-0.129 *(0.014)$ \\
\hline High School Diploma & & $-0.140 *(0.012)$ & $-0.129 *(0.012)$ & $-0.119 *(0.013)$ & $-0.132 *(0.013)$ \\
\hline Some College & & $-0.066 *(0.012)$ & $-0.053 *(0.013)$ & $-0.046 *(0.013)$ & $-0.067 *(0.013)$ \\
\hline Renter (vs. owner) & & $-0.049 *(0.012)$ & $-0.068 *(0.012)$ & $-0.073 *(0.012)$ & $-0.011(0.013)$ \\
\hline \multicolumn{6}{|l|}{ Acculturation } \\
\hline \multicolumn{6}{|c|}{ Years in the United States (ref. = Native-Born) } \\
\hline $0-5$ years & & & $0.062 *(0.013)$ & $0.046 *(0.013)$ & $0.048 *(0.014)$ \\
\hline $6-10$ years & & & $0.055 *(0.013)$ & $0.041 *(0.013)$ & $0.045 *(0.014)$ \\
\hline $11-15$ years & & & $0.052 *(0.013)$ & $0.041 *(0.013)$ & $0.038 *(0.014)$ \\
\hline $16-20$ years & & & $0.017(0.013)$ & $0.009(0.013)$ & $0.017(0.014)$ \\
\hline $21+$ years & & & $-0.024(0.015)$ & $-0.015(0.015)$ & $-0.009(0.016)$ \\
\hline \multicolumn{6}{|c|}{ English Language Ability (ref. = Speak English Only) } \\
\hline Speaks English very well or well & & & $0.002(0.017)$ & $0.002(0.018)$ & $0.08(0.019)$ \\
\hline Speaks English not well or not at all & & & $-0.042 *(0.015)$ & $-0.032 *(0.015)$ & $-0.045 *(0.016)$ \\
\hline \multicolumn{6}{|l|}{ Family/Household Status } \\
\hline Sex (ref. = Male) & & & & $-0.022(0.013)$ & $-0.026^{* *}(0.014)$ \\
\hline \multicolumn{6}{|l|}{ Age of householder (ref. $=35-44$ ) } \\
\hline $25-34$ & & & & $0.025 * *(0.013)$ & $0.018(0.014)$ \\
\hline $45-54$ & & & & $-0.052 *(0.014)$ & $-0.038 *(0.014)$ \\
\hline $55-64$ & & & & $-0.103 *(0.015)$ & $-0.09 *(0.016)$ \\
\hline
\end{tabular}


Table A1. Cont.

\begin{tabular}{|c|c|c|c|c|c|}
\hline & Model I & Model II & Model III & Model IV & Model V \\
\hline \multicolumn{6}{|l|}{ Marital Status (ref. = Married) } \\
\hline Never Married & & & & $-0.113 *(0.013)$ & $-0.092 *(0.014)$ \\
\hline Others & & & & $-0.02(0.012)$ & $-0.03 *(0.013)$ \\
\hline \multicolumn{6}{|c|}{ Number of Families in Household (ref. = 1 Family) } \\
\hline $1+$ family & & & & $-0.027 *(0.011)$ & $-0.046 *(0.011)$ \\
\hline \multicolumn{6}{|c|}{ Number of persons in household (ref. $=1-2$ persons) } \\
\hline 3-4 Persons & & & & $-0.021(0.014)$ & $-0.031 *(0.014)$ \\
\hline $4+$ Persons & & & & $-0.085 *(0.013)$ & $-0.094 *(0.014)$ \\
\hline \multicolumn{6}{|c|}{ Children Under 18 Present in Household (ref. $=$ Children $<18$ Present) } \\
\hline No Children Present $<18$ & & & & $0.009(0.015)$ & $-0.003(0.015)$ \\
\hline \multicolumn{6}{|l|}{ Region (ref. = Northeast) } \\
\hline Midwest & & & & & $0.217 *(0.012)$ \\
\hline South & & & & & $0.887 *(0.015)$ \\
\hline West & & & & & $0.469 *(0.013)$ \\
\hline $\mathrm{N}$ & & & 10,000 & & \\
\hline Constant & 0.614 & 0.620 & 0.622 & 0.625 & 0.697 \\
\hline
\end{tabular}

Source: 2012-2016 American Community Survey (ACS); ${ }^{*} p<0.05$; ** $p<0.10$.

Table A2. Group Specific Logisitic Regression Results Predicting Developing (vs. Mature) Suburban Outcomes-Standardized Coefficients (Standard Errors).

\begin{tabular}{|c|c|c|c|c|c|c|c|c|}
\hline \multirow[b]{2}{*}{ Socioeconomic Status } & \multicolumn{2}{|c|}{ White } & \multicolumn{2}{|c|}{ Black } & \multicolumn{2}{|c|}{ Asian } & \multicolumn{2}{|c|}{ Hispanic } \\
\hline & Coef & SE & Coef & SE & Coef & SE & Coef & SE \\
\hline \multicolumn{9}{|c|}{ Household Income (ref. $=\$ 120,000$ and up) } \\
\hline$\$ 0-\$ 19,999$ & $-0.150 *$ & 0.032 & $-0.164 *$ & 0.030 & $-0.084 *$ & 0.034 & -0.005 & 0.030 \\
\hline$\$ 20,000-\$ 39,999$ & $-0.157 *$ & 0.031 & $-0.135 *$ & 0.032 & $-0.066^{*}$ & 0.032 & -0.019 & 0.030 \\
\hline$\$ 40,000-\$ 59,999$ & $-0.216^{*}$ & 0.028 & -0.172 * & 0.031 & -0.096 * & 0.030 & -0.013 & 0.029 \\
\hline$\$ 60,000-\$ 79,999$ & $-0.104 *$ & 0.025 & -0.126 * & 0.030 & -0.029 & 0.028 & -0.015 & 0.028 \\
\hline$\$ 80,000-\$ 99,999$ & $-0.072 *$ & 0.023 & $-0.068 *$ & 0.030 & 0.003 & 0.027 & -0.024 & 0.028 \\
\hline$\$ 100,000-\$ 119,000$ & -0.013 & 0.023 & $-0.063 *$ & 0.029 & $-0.045 * *$ & 0.024 & -0.026 & 0.027 \\
\hline \multicolumn{9}{|c|}{ Education of householder (ref. $=$ College degree or more) } \\
\hline Less than High School Diploma & -0.047 & 0.037 & $-0.19 *$ & 0.029 & $-0.149 *$ & 0.031 & $-0.105^{*}$ & 0.023 \\
\hline High School Diploma & $-0.06^{*}$ & 0.025 & $-0.182 *$ & 0.027 & $-0.13 *$ & 0.033 & $-0.118^{*}$ & 0.028 \\
\hline Some College & -0.029 & 0.025 & $-0.094 *$ & 0.027 & $-0.107^{*}$ & 0.030 & -0.039 & 0.029 \\
\hline Renter (vs. owner) & $-0.068 *$ & 0.029 & $0.044^{* *}$ & 0.026 & $-0.079 *$ & 0.029 & 0.006 & 0.025 \\
\hline
\end{tabular}


Table A2. Cont.

\begin{tabular}{|c|c|c|c|c|c|c|c|c|}
\hline Acculturation & \multicolumn{2}{|c|}{ White } & \multicolumn{2}{|c|}{ Black } & \multicolumn{2}{|c|}{ Asian } & \multicolumn{2}{|c|}{ Hispanic } \\
\hline \multicolumn{9}{|c|}{ Years in the United States (ref. = Native-Born) } \\
\hline $0-5$ years & -0.031 & 0.068 & -0.001 & 0.039 & 0.054 & 0.021 & 0.076 & 0.027 \\
\hline $6-10$ years & 0.091 & 0.077 & 0.019 & 0.035 & 0.064 & 0.023 & 0.042 & 0.024 \\
\hline $11-15$ years & 0.056 & 0.074 & 0.043 & 0.037 & 0.036 & 0.025 & 0.046 & 0.022 \\
\hline $16-20$ years & 0.015 & 0.062 & -0.041 & 0.036 & 0.053 & 0.025 & -0.007 & 0.022 \\
\hline $21+$ years & -0.02 & 0.056 & -0.037 & 0.037 & 0.046 & 0.034 & -0.034 & 0.025 \\
\hline \multicolumn{9}{|c|}{ English Language Ability (ref. = Speak English Only) } \\
\hline Speaks English very well or well & -0.013 & 0.059 & $-0.076^{* *}$ & 0.046 & $0.086^{*}$ & 0.034 & -0.044 & 0.029 \\
\hline Speaks English not well or not at all & 0.104 & 0.094 & -0.018 & 0.068 & -0.022 & 0.028 & $-0.087^{*}$ & 0.023 \\
\hline \multicolumn{9}{|l|}{ Family/Household Status } \\
\hline Sex (ref. = Male) & -0.027 & 0.026 & 0.034 & 0.028 & -0.131 * & 0.032 & 0.004 & 0.030 \\
\hline \multicolumn{9}{|l|}{ Age of householder (ref. $=35-44$ ) } \\
\hline $25-34$ & 0.026 & 0.030 & 0.040 & 0.029 & -0.018 & 0.029 & 0.034 & 0.025 \\
\hline $45-54$ & $-0.074^{*}$ & 0.029 & $-0.059 *$ & 0.030 & $-0.055^{* *}$ & 0.030 & 0.022 & 0.028 \\
\hline $55-64$ & $-0.099 *$ & 0.031 & -0.104 * & 0.032 & $-0.092 *$ & 0.033 & $-0.065 *$ & 0.032 \\
\hline \multicolumn{9}{|l|}{ Marital Status (ref. = Married) } \\
\hline Never Married & $-0.136 *$ & 0.029 & $-0.057 *$ & 0.026 & -0.077 * & 0.033 & $-0.103 *$ & 0.026 \\
\hline Others & 0.012 & 0.026 & -0.04 & 0.026 & -0.036 & 0.033 & -0.034 & 0.025 \\
\hline \multicolumn{9}{|c|}{ Number of Families in Household (ref. = 1 Family) } \\
\hline 1+ family & -0.098 * & 0.026 & -0.021 & 0.024 & $-0.065^{*}$ & 0.024 & -0.015 & 0.020 \\
\hline \multicolumn{9}{|c|}{ Number of persons in household (ref. $=1-2$ persons) } \\
\hline 3-4 Persons & 0.019 & 0.029 & $-0.055^{* *}$ & 0.029 & -0.042 & 0.031 & $-0.077^{*}$ & 0.030 \\
\hline 4+ Persons & -0.019 & 0.031 & -0.093 * & 0.030 & -0.131 * & 0.029 & -0.111 * & 0.027 \\
\hline \multicolumn{9}{|c|}{ Children Under 18 Present in Household (ref. = Children $<18$ Present) } \\
\hline No Children Present $<18$ & 0.022 & 0.032 & 0.016 & 0.029 & 0.004 & 0.035 & -0.035 & 0.030 \\
\hline \multicolumn{9}{|l|}{ Region (ref. = Northeast) } \\
\hline Midwest & $0.219 *$ & 0.019 & $0.123 *$ & 0.024 & $0.404 *$ & 0.031 & $0.217^{*}$ & 0.031 \\
\hline South & $0.848 *$ & 0.029 & $0.875^{*}$ & 0.028 & $0.792 *$ & 0.035 & $0.984^{*}$ & 0.030 \\
\hline West & $0.592 *$ & 0.031 & $0.637^{*}$ & 0.038 & $0.416^{*}$ & 0.024 & & 0.025 \\
\hline $\mathrm{N}$ & & & & & & & $0.45 *$ & \\
\hline Constant & 0.714 & & 0.533 & & 0.905 & & 0.555 & \\
\hline Nagelkerke R Square & & & & & & & & \\
\hline
\end{tabular}

Source: 2012-2016 American Community Survey (ACS); * $p<0.05 ; * *<0.10$. 


\section{References}

Adelman, Robert, Hui-Shien Tsao, Stewart Tolnay, and Kyle Crowder. 2001. Neighborhood Disadvantage among Racial and Ethnic Groups: Residential Location in 1970 and 1980. The Sociological Quarterly 42: 603-32. [CrossRef]

Alba, Richard, and John R. Logan. 1991. Variation on Two Themes: Racial and Ethnic Patterns in Attainment of Suburban Residence. Demography 28: 431-53. [CrossRef] [PubMed]

Alba, Richard, and John R. Logan. 1993. Minority Proximity to Whites in the Suburbs: An Individual Analysis of Segregation. American Journal of Sociology 98: 1388-427. [CrossRef]

Alba, Richard, and Victor Nee. 1997. Rethinking Assimilation Theory for a New Era of Immigration. International Migration Review 31: 826-74. [CrossRef] [PubMed]

Alba, Richard, and Victor Nee. 2003. Remaking the American Mainstream: Assimilation and Contemporary Immigration. Cambridge: Harvard University Press.

Alba, Richard, John Logan, Brian Stults, Gilbert Marzan, and Wenquan Zhang. 1999. Immigrant Groups in Suburbs: A Reexamination of Suburbanization and Spatial Assimilation. American Sociological Review 64: 446-60. [CrossRef]

Alba, Richard, John Logan, and Brian Stults. 2000. The Changing Neighborhood Contexts of the Immigrant Metropolis. Social Forces 79: 587-621. [CrossRef]

Allard, W. Scott. 2017. Places in Need: The Changing Geography of Poverty. New York: Russell Sage Foundation.

Anacker, Katrin B. 2015a. Analyzing Census Tract Foreclosure Risk Rates in Mature and Developing Suburbs in the United States. Urban Geography 36: 1221-40. [CrossRef]

Anacker, Katrin B. 2015b. The New American Suburb: Poverty, Race, and the Economic Crisis. Burlington: Ashgate.

Anacker, Katrin B., Christopher Niedt, and Chang Kwon. 2017. Analyzing Segregation in Mature and Developing Suburbs in the United States. Journal of Urban Affairs 39: 819-32. [CrossRef]

Capps, Randy, James D. Bachmeier, and Jennifer Van Hook. 2018. Estimating the Characteristics of Unauthorized Immigrants Using U.S. Census Data: Combined Sample Multiple Imputation. The ANNALS of the American Academy of Political and Social Science 677: 165-79. [CrossRef]

Charles, Camille Z. 2003. The Dynamics of Racial Residential Segregation. Annual Review of Sociology 29: 167-207. [CrossRef]

Charles, Camille Z. 2006. Won't You Be My Neighbor? Race, Residence, and Inter-Group Relations in Los Angeles. New York: Russell Sage Foundation.

Coley, Rebekah Levine, Tama Leventhal, Alicia Doyle Lynch, and Melissa Kull. 2013. Relations between Housing Characteristics and the Well-Being of Low-Income Children and Adolescents. Developmental Psychology 49: 1775-89. [CrossRef] [PubMed]

Crowell, Amber R., and Mark Fossett. 2018. White and Latino Locational Attainments: Assessing the Roles of Race and Resources in U.S. Metropolitan Residential Segregation. Sociology of Race and Ethnicity 4: 491-507. [CrossRef]

Evans, Gary W., Nancy M. Wells, Hoi-Yan Erica Chan, and Heidi Saltzman. 2000. Housing Quality and Mental Health. Journal of Consulting and Clinical Psychology 68: 526-30. [CrossRef] [PubMed]

Farrell, R. Chad. 2016. Immigrant Suburbanisation and the Shifting Geographic Structure of Metropolitan Segregation in the United States. Urban Studies 53: 57-76. [CrossRef]

Farrell, Chad R., and Glenn Firebaugh. 2016. Is immigrant neighborhood inequality less pronounced in suburban areas? Social Science Research 57: 161-76. [CrossRef] [PubMed]

Frey, William. 2015. Diversity Explosion. Washington: Brookings Institution Press.

Frey, William, and Alden Speare. 1988. Regional and Metropolitan Growth and Decline in the United States. New York: Russell Sage Foundation.

Friedman, Samantha, and Emily Rosenbaum. 2005. Does Suburban Residence Mean Better Neighborhood Conditions for all Households? Assessing the Influence of Nativity Status and Race/Ethnicity. Social Science Research 36: 1-27. [CrossRef]

Gallagher, Leigh. 2013. The End of the Suburbs: Where the American Dream is Moving. New York: Portfolio.

Gordon, Milton M. 1964. Assimilation in American Life. New York: Oxford University Press.

Green Leigh, Nancey, and Sugie Lee. 2005. Philadelphia's Space In Between: Inner-Ring Suburb Evolution. Opolis 1: $13-32$. 
Hanlon, Bernadette. 2009. A Typology of Inner-Ring Suburbs: Class, Race, and Ethnicity in U.S. Suburbia. City and Community 8: 221-46. [CrossRef]

Hanlon, Bernadette. 2010. Once the American Dream: Inner-Ring Suburbs of the Metropolitan United States. Philadelphia: Temple University Press.

Hanlon, Bernadette, and Thomas J. Vicino. 2007. The Fate of Inner Suburbs: Evidence from Metropolitan Baltimore. Urban Geography 28: 249-75. [CrossRef]

Holliday, Amy, and Rachel Dwyer. 2009. Suburban Neighborhood Poverty in U.S. Metropolitan Areas in 2000. City and Community 8: 155-76. [CrossRef]

Hudnut, William H. 2003. Halfway to Everywhere: A Portrait of America's First-Tier Suburbs. Washington: Urban Land Institute.

Kneebone, Elizabeth, and Alana Berube. 2013. Confronting Suburban Poverty in America. Washington: Brookings Institution Press.

Lee, Sugie, and Nancey Green Leigh. 2007. Intrametropolitan Spatial Differentiation and Decline of Inner-Ring Suburbs: A Comparison of Four US Metropolitan Areas. Journal of Planning Education and Research 27: 146-64. [CrossRef]

Logan, John R., and Richard D. Alba. 1991. Variations on Two Themes: Racial and Ethnic Patterns in the Attainment of Suburban Residence. Demography 28: 431-53.

Logan, John R., and Richard D. Alba. 1993. Locational Return to Human Capital: Minority Access to Suburban Community Resources. Demography 30: 243-68. [CrossRef] [PubMed]

Logan, John R., and Harvey Molotch. 1987. Urban Fortunes. Berkeley: University of California Press.

Logan, John R., Richard D. Alba, and Shu-Yin Leung. 1996. Minority Access to White Suburbs: A Multiregional Comparison. Social Forces 74: 851-81. [CrossRef]

Logan, John R., Richard D. Alba, Tom McNulty, and Brian Fisher. 1996. Making a Place in the Metropolis: Locational Attainment in Cities and Suburbs. Demography 33: 443-53. [CrossRef] [PubMed]

Logan, John R., Zhang Wenquan, and Richard Alba D. 2002. Immigrant Enclaves and Ethnic Communities in New York and Los Angeles. American Sociological Review 67: 299-322. [CrossRef]

Lucy, William H., and David L. Phillips. 2000. Confronting Suburban Decline: Strategic Planning or Metropolitan Renewal. Washington: Island Press.

Lucy, William H., and David L. Phillips. 2006. Tomorrow's Cities, Tomorrow's Suburbs. Chicago: Planners Press.

Massey, Douglas. 1985. Ethnic Residential Segregation: A Theoretical Synthesis and Empirical Review. Sociology and Social Science Research 69: 315-50.

Massey, Douglas, and Nancy Denton. 1988. Suburbanization and Segregation in U.S. Metropolitan Areas. American Journal of Sociology 94: 592-626. [CrossRef]

Massey, Douglas, and Brendan Mullan. 1985. Processes of Hispanic and Black Spatial Assimilation. American Journal of Sociology 89: 836-73. [CrossRef]

Oh, Sun Jung, and John Yinger. 2015. What Have We Learned from Paired Testing in Housing Markets? Cityscape 17: 15-60.

Pfeiffer, Deirdre. 2012. Has Exurban Growth Enabled Greater Racial Equity in Neighborhood Quality? Evidence from the Los Angeles Region. Journal of Urban Affairs 34: 347-71. [CrossRef]

Pfeiffer, Deirdre. 2016. Racial Equity in the Post-Civil Rights Suburbs? Evidence from US Regions 2000-2012. Urban Studies 53: 799-817. [CrossRef]

Puentes, Robert, and Myron Orfield. 2002. Valuing America's First Suburbs: A Policy Agenda for Older Suburbs in the Midwest. Washington: The Brookings Institution Press.

Rosenbaum, Emily. 1996. Racial/Ethnic Differences in Home Ownership and Housing Quality, 1991. Social Problems 43: 403-26. [CrossRef]

Rosenbaum, Emily, and Samantha Friedman. 2004. Generational Patterns in Home Ownership and Housing Quality among Racial/Ethnic Groups in New York City, 1999. The International Migration Review 38: 1492-533. [CrossRef]

Rosenbaum, Emily, and Samantha Friedman. 2007. The Housing Divide: How Generations of Immigrants Fare in New York's Housing Market. New York: New York University Press.

Rossi, Peter. 1955. Why Families Move: A Study in the Social Psychology of Urban Residential Mobility. Glencoe: Free Press. 
Rothstein, Richard. 2017. The Color of Law: The Forgotten History of How Our Government Segregated America. New York: Liveright Publishing.

Sampson, Robert J. 2012. The Great American City: Chicago and the Enduring Neighborhood Effect. Chicago: University of Chicago Press.

Sampson, Robert J., Jeffrey D. Morenoff, and Thomas Gannon-Rowley. 2002. Assessing "Neighborhood effects": Social Processes and New Directions in Research. Annual Review of Sociology 28: 443-78. [CrossRef]

Schaefer-McDaniel, Nicole. 2009. Neighborhood Stressors, Perceived Neighborhood Quality, and Child Mental Health in New York City. Health Place 15: 148-55. [CrossRef] [PubMed]

Sharkey, Patrick. 2013. Stuck in Place: Urban Neighborhoods and the End of Progress Toward Racial Equality. Chicago: University of Chicago Press.

Short, John Rennie, Bernadette Hanlon, and Thomas J. Vicino. 2007. The Decline of Inner Suburbs: The New Suburban Gothic in the United States. Geography Compass 1: 641-56. [CrossRef]

South, Scott J., and Kyle D. Crowder. 1997. Escaping Distressed Neighborhoods: Individual, Community, and Metropolitan Influences. American Journal of Sociology 102: 1040-84. [CrossRef]

South, Scott J., and Kyle Crowder. 1998. Leaving the 'Hood: Residential Mobility between Black, White, and Integrated Neighborhoods. American Sociological Review 63: 17-26. [CrossRef]

South, Scott J., and Glenn Deane. 1993. Race and Residential Mobility: Individual Determinants and Structural Constraints. Social Forces 72: 147-67. [CrossRef]

South, Scott J., Kyle Crowder, and Erick Chavez. 2005. Geographic Mobility and Spatial Assimilation among U.S. Latino Immigrants. International Migration Review 39: 577-607. [CrossRef]

Steven Ruggles, Sarah Flood, Ronald Goeken, Josiah Grover, Erin Meyer, Jose Pacas, and Matthew Sobek. 2018. IPUMS USA: Version 8.0 [Dataset]. Minneapolis: IPUMS.

Swanstrom, Todd, Colleen Casey, Robert Flack, and Peter Dreier. 2004. Pulling Apart: Economic Segregation among Suburbs and Central Cities in Major Metropolitan Areas. Washington: Brookings Institution Press.

Tabachnick, Barbara G., and Linda S. Fidell. 2001. Using Multivariate Statistics, 4th ed. Boston: Allyn and Bacon.

Timberlake, Jeffrey M., Aaron J. Howell, and Amanda J. Staight. 2011. Trends in the Suburbanization of Racial/Ethnic Groups in U.S. Metropolitan Areas, 1970 to 2000. Urban Affairs Review 47: 218-55. [CrossRef]

Turner, Margery A., and Stephen L. Ross. 2005. How racial discrimination affects the search for housing. In The Geography of Opportunity: Race and Housing Choice in Metropolitan America. Edited by Souzade Briggs. Washington: Brookings Institution Press, pp. 81-100.

Turner, Margery A., Stephen Ross, George Galster, and John Yinger. 2002. Discrimination in Metropolitan Housing Markets: National Results from Phase I HDS 2000; Washington: U.S. Department of Housing and Urban Development.

Turner, Margery, Rob Santos, Diane Levy, Doug Wissoker, Claudia L. Aranda, and Rob Ptingolo. 2013. Housing Discrimination against Racial and Ethnic Minorities 2012; Washington: U.S. Department of Housing and Urban Development.

U.S. Census Bureau. 2012. Newsroom: Census Bureau Releases Estimates of Undercount and Overcount in the 2010 Census; Washington: U.S. Census Bureau. Available online: https:/ /www.census.gov/newsroom/releases/ archives/2010_census/cb12-95.html (accessed on 8 June 2017).

Walker, Kyle E. 2017. The Shifting Destinations of Metropolitan Migrants in the U.S., 2005-2011. Growth and Change 48: 532-51. [CrossRef]

Wilkes, Rima, and John Iceland. 2004. Hypersegregation in the Twenty-First Century: An Update and Analysis. Demography 41: 23-36. [CrossRef] [PubMed]

Wilson, Jill, and Audrey Singer. 2011. Immigrants in 2010 Metropolitan America: A Decade of Change. Washington: Brookings Institution.

Woldoff, Rachael A. 2008. Wealth, Human Capital, and Family across Racial/Ethnic Groups: Integrating Models of Wealth and Locational Attainment. Urban Studies 45: 527-51. [CrossRef]

Yinger, John. 1995. Closed Doors, Opportunities Lost: The Continuing Costs of Housing Discrimination. New York: Russell Sage Foundation.

(C) 2018 by the author. Licensee MDPI, Basel, Switzerland. This article is an open access article distributed under the terms and conditions of the Creative Commons Attribution (CC BY) license (http://creativecommons.org/licenses/by/4.0/). 